\title{
PENGARUH KESADARAN, PERSEPSI DAN PREFERENSI KONSUMEN TERHADAP PERILAKU KONSUMEN DALAM MENGKONSUMSI BUAH LOKAL DI KAWASAN PERPASARAN JAKARTA BARAT
}

\author{
Nailul Murod, Siti Rochaeni* dan Lilis Imamah Ichdayati
}

\begin{abstract}
ABSTRAK
Tujuan dari penelitian ini adalah untuk mengetahui pengaruh kesadaran, persepsi, dan preferensi konsumen pada perilaku konsumen dalam mengkonsumsi buah-buahan lokal. Penelitian ini dilakukan di Slipi, Hypermart Puri Indah, Supermarket Kebon Jeruk, Minimarket di daerah Kembangan, dan khusus Toko dari Rezeky Buah Segar Center. Sebanyak 100 responden diwawancarai dengan menggunakan teknik accidental sampling. Analisis deskriptif dan analisis regresi berganda digunakan untuk menganalisis data. Hasil penelitian menunjukkan bahwa variabel kesadaran, persepsi dan preferensi pelanggan secara signifikan mempengaruhi perilaku konsumen dalam mengkonsumsi buah lokal.
\end{abstract}

Kata kunci: buah, konsumsi, ritel, regresi lokal

\begin{abstract}
The purpose of this study is to determine the effect of consciousnesses, perceptions, and consumer preferences on consumer behaviors in consuming local fruits. The research was conducted in Slipi, Hypermart Puri Indah, Supermarket Kebon Jeruk, Minimarket in Kembangan area, and Specialty Stores of Rezeky Fresh Fruit Center. A total of 100 respondents were interviewed by using accidental sampling technique. Analysis descriptions and multiple regression analysis were employed to analyze the data. The results showed that the variables of consciousnesses, perceptions and customer preferences significantly affect consumer behavior in consuming local fruit.
\end{abstract}

Keywords: local fruit, consumtion, retail, multiple regression

\section{PENDAHULUAN}

Kesadaran dapat dikatakan sebagai tahap pertama dari proses adopsi terhadap suatu produk atau ide baru. Kesadaran mengenai produk hanya sebatas kesadaran konsumen atas keberadaan suatu produk, namun informasi yang diketahui seputar produk tersebut masih sangat sedikit. Kesadaran atas suatu produk dibangun oleh kebutuhan, pengetahuan tentang atribut produk baru, pengalaman konsumsi di masa lalu, dan juga keinovatifan seseorang.

Menurut Simamora (2002 : 102) persepsi dapat didefinisikan sebagai suatu proses dengan mana seorang menyeleksi, mengorganisasikan, dan menginterpretasikan stimuli ke dalam suatu gambaran dunia yang berarti dengan menyeluruh. Persepsi tidak saja penting dalam tahapan pemprosesan informasi melalui stimuli 
namun juga berperan pada pasca konsumsi produk yaitu ketika konsumen melakukan evaluasi atas keputusan pembeliannya. Apakah konsumen merasa puas atau sebaliknya, penilaian inipun tidak lepas dari persepsi mereka.

Preferensi konsumen merupakan suatu cara praktis untuk menggambarkan bagaimana orang lebih suka terhadap suatu barang lebih dari yang lain (Pindyc dan Rubenfield, 2002 : 64). Menurut Elizabeth dan Sanjur (1982) dalam Suharjo (1989 : 186) ada tiga faktor utama yang mempengaruhi konsumsi pangan dalam hubungannya dengan preferensi yaitu karakteristik individu (umur, jenis kelamin, suku, pendapatan), karakteristik makanan (rasa, warna, harga) dan karakteristik lingkungan (musim, pekerjaan, dan tingkat sosial didalam masyarakat).

Pengaruh dari kesadaran, persepsi, dan preferensi konsumen terhadap perilaku konsumen dalam mengkonsumsi buah lokal adalah bahwasanya konsumen diasumsikan mampu membuat peta posisi pemikiran yang merupakan gambaran kesadaran, persepsi dan preferensi konsumen sebagai penuntun dalam keputusan mengkonsumsi buah lokal. Oleh karena itu, agar buah lokal mampu bersaing secara optimal, maka produksi buah lokal harus tetap memperhatikan kesadaran, persepsi dan preferensi masyarakat setempat khususnya masyarakat di Jakarta Barat.

\section{METODE PENELITIAN}

\section{Lokasi dan Waktu Penelitian}

Penelitian ini dilakukan di daerah Jakarta Barat, dengan mengambil lima lokasi sebagai tempat survey konsumen yaitu Pasar Tradisional Slipi, Hypermart Puri Indah, Superindo Kebon Jeruk, Alfa Midi Kembangan, dan Rezeki Fresh Fruit Center Green Ville. Pemilihan lokasi penelitian ini dilakukan secara purposive (sengaja) dengan pertimbangan bahwa tempat tersebut menjual buah lokal segar. Alasan lain yang mendukung pemilihan lokasi tersebut dengan pertimbangan bahwa mata pencaharian masyarakat di Jakarta Barat didominasi dengan perdagangan, oleh karena itu lokasi penelitian di ambil sektor perpasaran dan sudah mendapatkan ijin untuk pengambilan sampel. Hal tersebut mendukung kemudahaan untuk mendapatkan responden. Waktu pengambilan data dilakukan pada bulan Juli-Agustus 2014.

\section{Jenis dan Sumber Data}

Jenis data yang digunakan dalam penelitian ini terdiri atas data primer dan data sekunder baik bersifat kuantitatif maupun kualitatif. Teknik pengumpulan data primer diperoleh melalui hasil wawancara langsung dengan konsumen buah yang menggunakan kuisioner sebagai alat bantu. Kuisioner atau juga dikenal angket merupakan salah satu teknik pengumpulan data dalam bentuk pengajuan pertanyaan tertulis melalui sebuah pertanyaan yang sudah dipersiapkan sebelumnya, dan harus diisi oleh responden (Sambas, 2007 : 25). Sedangkan data sekunder diperoleh dari pustaka-pustaka UIN Syarif Hidayatullah, BPS, Pemerintah Kota Jakarta Barat, Pemerintah Provinsi DKI Jakarta, internet dan informasi - informasi lain yang bersifat umum. 


\section{Metode Pengambilan Sampel}

Metode pengambilan sampel yang digunakan penulis adalah Nonprobability Sampling, yaitu teknik pengambilan sampel yang tidak memberi peluang/kesempatan sama bagi setiap unsur atau anggota populasi untuk dipilih menjadi sampel (Sugiyono, 2008:120). Dalam pengambilan sampling ini penulis menggunakan teknik Accidental Sampling, yaitu teknik penentuan sampel berdasarkan kebetulan, yaitu siapa saja yang secara kebetulan/insidental bertemu dengan peneliti dapat digunakan sebagai sampel, bila dipandang orang yang kebetulan ditemui itu cocok sebagai sumber data (Sugiyono, 2008 : 122).

Metode pengambilan sampel menggunakan Accidental Sampling, dimana responden dapat langsung dipilih di lokasi penelitian pada saat penelitian dilakukan. Pengumpulan data dari responden dilakukan melalui teknik wawancara. Responden yang dipilih adalah orang yang sedang membeli, telah membeli dan pernah mengkonsumsi buah lokal segar dan yang sudah pernah mengkonsumsi buah non-lokal di kawasan perpasaran Jakarta Barat dan bersedia diwawancarai. Setelah responden dipilih dan ditentukan, maka selanjutnya dilakukan wawancara berstruktur, yaitu teknik pengumpulan data melalui pertanyaan-pertanyaan berdasarkan panduan kuisioner. Wawancara yang dilakukan dengan 20 responden untuk setiap pasar yang sudah ditentukan, dari jumlah total 100 responden.

Paket kuisioner yang digunakan untuk keperluan wawancara terdiri dari dua bagian. Bagian pertama merupakan pertanyaan-pertanyaan yang berhubungan dengan identitas responden. Bagian kedua memuat pertanyaan-pertanyaan yang berhubungan dengan variabel kesadaran, persepsi, dan preferensi konsumen terhadap perilaku konsumen dalam mengkonsumsi buah lokal. Pertanyaan-pertanyaan yang dimuat dalam kuisioner merupakan pertanyaan tertutup, dimana responden memilih jawaban yang sesuai dengan pertanyaan yang diajukan.

Penentuan jumlah sampel dilakukan dengan cara perhitungan statistik yaitu dengan menggunakan Rumus Slovin (Umar 2003 : 146). Rumus Slovin digunakan untuk menentukan jumlah sampel dari populasi penduduk Jakarta Barat yang diketahui jumlahya yaitu sebanyak 2.396.600 jiwa untuk tingkat presisi yang ditetapkan dalam penentuan sampel adalah $10 \%$.

Rumus Slovin $=$

$\mathrm{n}=\frac{N}{1+N e} z=\frac{2396600}{1+2396600(0,1)}=99,99$

Dimana :

$n \quad=$ ukuran sampel

$\mathrm{N} \quad=$ ukuran populasi

$\mathrm{e}=\%$ kelonggaran ketidak telitian/kesalahan pengambilan sampel yang masih dapat ditolerir.

\section{Validasi Model}

Validasi merupakan langkah yang penting dalam pemodelan. Tujuan dari validasi model adalah untuk mengukur sejauh mana hasil model mendekati kondisi sebenarnya. Semakin dekat hasil model dengan kondisi lapangan, semakin valid model tersebut dalam menggambarkan populasi penduduk Jakarta Barat. 


\section{Pengujian Kuisioner}

Sebelum melakukan penyebaran kuisioner, peneliti melakukan pengujian pre-tes kuisioner. Uji validitas dan uji reliabilitas ini dilakukan terhadap 30 responden pretes, di luar jumlah responden yang dibutuhkan dalam penelitian ini yaitu 100 responden. Hal ini bertujuan agar kuisioner yang akan disebar kepada responden memiliki nilai valid dan reliabel yang baik. Atribut-atribut yang diuji dari 30 responden pre-tes kemudian diolah dengan uji validitas dan reliabilitas. Jika nilai validitas dan reliabilitasnya tinggi, maka kuisioner tersebut layak untuk dijadikan sebagai alat pengambilan data pada sampel di Kawasan Perpasaran Jakarta Barat.

\section{Validitas}

Uji validitas adalah suatu uji untuk mengukur ketepatan atau kecermatan. Instrumen dikatakan valid jika secara tepat mengukur apa yang ingin diukur. Pengujian validitas kuisioner pada penelitian ini dilakukan dengan menggunakan analisis Pearson yang ada pada software SPSS 18.0 for windows. Validitas suatu atribut dapat dilihat pada hasil output SPSS dengan menilai validitas melalui nilai Corrected Item-Total Correlation. Suatu atribut dikatakan valid jika nilai rhitung $>$ rtabel dengan taraf signifikansi 0,05 .

\section{Reliabillitas}

Pengujian reliabilitas dalam penelitian ini menggunakan formula software SPSS 18.0 for windows. Hasil reliabilitas suatu atribut dapat dilihat pada hasil output SPSS pada tabel dengan judul Reliability Statistics. Menilai reliabilitas atau tidaknya suatu atribut dapat dilihat dari nilai Alpha
Cronbach. Suatu atribut dikatakan reliabel jika nilai alpha cronbach diatas 0,60 dan sebaliknya.

\section{Uji Asumsi Klasik}

Untuk menguji apakah persamaan garis regresi yang diperoleh linier dan bisa dipergunakan untuk melakukan peramalan, maka harus dilakukan uji asumsi klasik yang digunakan menurut Ghozali (2006 : 96), yaitu :

\section{Uji Normalitas}

Uji normalitas bertujuan untuk mengetahui apakah dalam model regresi, variabel terikat dan variabel bebas memiliki distribusi normal atau tidak, karena model regresi yang baik memiliki distribusi data yang normal atau mendekati normal.

\section{Uji Multikolinearitas}

Multikolinearitas dapat dideteksi dengan menganalisis matrik korelasi variabel-variabel independen atau dengan menggunakan perhitungan nilai Tolerance dan VIF. Jika antar variabel independen ada korelasi yang cukup tinggi (lebih dari 0,900) maka hal ini menunjukkan adanya multikolinearitas atau jika nilai Tolerance kurang dari 0,100 atau nilai VIF lebih dari 10 , maka hal ini menunjukkan adanya multikolinearitas.

\section{Uji Heteroskedastisitas}

Tujuan pengujian ini adalah untuk mengetahui apakah dalam model regresi terjadi ketidaksamaan variance dari residual satu pengamatan ke pengamatan yang lain. Jika variance dari residual satu pengamatan ke pengamatan yang lain tetap maka 
disebut homokedastisitas, namun jika berbeda disebut dengan heterokedastisitas. Model regresi yang baik adalah homokedastisitas atau tidak terjadi heterokedastisitas.

\section{Analisis Regresi Linier Berganda}

Metode ini digunakan untuk menentukan ketetapan prediksi dan untuk melengkapi analisis sejauh mana variabel bebas berpengaruh terhadap variabel terikat. Dalam penelitian ini persamaan regresi mengacu kepada Sugiyono (1997:235) sebagai berikut : $\mathrm{Y}=\alpha+\mathrm{b}_{1} \mathrm{X}_{1}+\mathrm{b}_{2} \mathrm{X}_{2}+\mathrm{b}_{3} \mathrm{X}_{3}+e$

Dimana :

$\mathrm{Y}=$ Perilaku Mengkonsumsi Buah Lokal

A = Bilangan konstanta sebagai titik potong

$\mathrm{b}_{1}, \mathrm{~b}_{2}, \mathrm{~b}_{3}=$ Koefisien regresi $\mathrm{X}_{1}, \mathrm{X}_{2}$, $\mathrm{X} 3$

$\mathrm{X}_{1}=$ Kesadaran konsumen

$\mathrm{X}_{2}=$ Persepsi konsumen

X3 = Preferensi konsumen

$\mathrm{e}=$ Standar kesalahan

Analisis regresi perlu dilakukan untuk mengaplikasikan model regresi sebagai berikut :

1. Koefisien Determinasi $\left(\mathrm{R}^{2}\right)$

Koefisien

Determinasi

digunakan untuk mengetahui seberapa jauh variabel dependen yang dapat diterangkan oleh variabel independen.

2. Uji Signifikansi Penduga yang digunakan adalah uji $\mathrm{F}$

Uji $F$ bertujuan untuk mengetahui apakah regresi linier berganda berikut perhitungan koefisien regresinya menunjukkan ada pengaruh signifikan atau tidak maka terlebih dahulu perlu dilakukan pengujian dengan analisis F hitung

3. Uji untuk Masing-masing Parameter yang digunakan adalah Uji t

Uji $\mathrm{t}$ digunakan untuk menunjukkan apakah suatu variabel independen secara individual mempengaruhi variabel dependen.

\section{HASIL DAN PEMBAHASAN}

Metode regresi linier berganda membantu dalam mengetahui besarnya pengaruh variabel independen yaitu kesadaran, persepsi, dan preferensi konsumen terhadap variabel dependen yang dalam penelitian ini yaitu Perilaku Konsumen dalam Mengkonsumsi Buah Lokal. Berdasarkan data primer yang telah didapatkan melalui wawancara dengan responden menggunakan kuisioner di Kawasan Perpasaran Jakarta Barat kemudian diolah dengan menggunakan SPSS 18. Sebelum melakukan analisis regresi linier berganda, data primer yang telah didapatkan sudah melewati uji validitas dan reabilitas data serta telah memenuhi pengujian asumsi klasik yang berupa pengujian : Normalitas, Multikolinieritas, dan Heteroskedastisitas

Diperoleh model perilaku konsumen dalam mengkonsumsi buah lokal di Kawasan Perpasaran Jakarta Barat sebagai berikut : $\mathrm{Y}=-0,367+$ $0,369 X_{1}+0,266 X_{2}+0,432 X_{3}$

Berdasarkan model Perilaku Konsumen dalam Mengkonsumsi Buah Lokal di Kawasan Perpasaran Jakarta Barat diduga nilai konstanta bernilai 0,367 bila variabel $X_{1}, X_{2}$, dan $X_{3}$ 
sama dengan nol. Uji koefisien determinasi digunakan untuk melihat seberapa besar variabel independen (kesadaran, persepsi, dan preferensi konsumen) menjelaskan variabel dependen berupa Perilaku Konsumen dalam Mengkonsumsi Buah Lokal di Kawasan Perpasaran Jakarta Barat.

\section{Pengaruh Kesadaran Terhadap Perilaku Konsumen dalam Mengkonsumsi Buah Lokal di Kawasan Perpasaran Jakarta Barat} Hasil dugaan pengaruh kesadaran (X1) terhadap Perilaku Konsumen dalam Mengkonsumsi Buah Lokal (Y) adalah sebesar 0,369 dan nilai koefisien bertanda positif, artinya jika tingkat kesadaran naik satu satuan, maka akan menyebabkan bertambahnya peluang Perilaku Konsumen dalam Mengkonsumsi Buah Lokal diwilayah Jakarta Barat sebesar 0,369 satuan dengan menganggap variabel yang lain konstan. Pada pengujian kesadaran $\left(\mathrm{X}_{1}\right)$ terhadap Perilaku Konsumen dalam Mengkonsumsi Buah Lokal pada tingkat kepercayaan 95\% menunjukan bahwa nilai thitung sebesar 3,824 lebih besar dari nilai tTabel $(3,824>$ 1,985) dan memiliki nilai signifikansi lebih kecil dari nilai $\alpha(0,000<0,05)$ sehingga berdasarkan hal tersebut, variabel independen kesadaran berpengaruh nyata (signifikan) terhadap variabel dependen Perilaku Konsumen dalam Mengkonsumsi Buah Lokal. Hal ini menunjukan bahwa kesadaran adalah faktor yang paling mendasari konsumen dalam membeli buah lokal di Kawasan Perpasaran Jakarta Barat.

Berdasarkan karakteristik responden dapat diketahui bahwa konsumen di kawasan perpasaran
Jakarta Barat mayoritas adalah wanita, usia antara 35-42 tahun dengan status sudah menikah, jenis pekerjaan karyawan dengan berpenghasilan Rp. 2.400.001,00 - Rp. $5.000 .000,00$ yang mempunyai pengetahuan konsumen, kebutuhan, keinovatifan dan pengalaman konsumsi masa lalu konsumen di Kawasan Perpasaran Jakarta Barat berada pada kategori tinggi. Dengan demikian, kesadaran responden mengenai Perilaku Konsumen dalam Mengkonsumsi Buah Lokal di Kawasan Perpasaran Jakarta Barat sudah baik.

Berdasarkan penjelasan diatas, dapat disimpulkan bahwa terdapat kesesuaian dengan teori kesadaran konsumen mengenai suatu produk diukur untuk mengetahui sejauh mana pengetahuan konsumen yang disasar mengenai keberadaan produk tersebut (Peter \& Olson 1996 : 168).

\section{Pengaruh Persepsi Konsumen Terhadap Perilaku Konsumen dalam Mengkonsumsi Buah Lokal di Kawasan Perpasaran Jakarta Barat}

Hasil dugaan pengaruh persepsi (X2) terhadap Perilaku Konsumen dalam Mengkonsumsi Buah Lokal (Y) adalah sebesar 0,266 dan nilai koefisien bertanda positif, artinya jika tingkat persepsi naik satu satuan, maka akan menyebabkan bertambahnya peluang Perilaku Konsumen dalam Mengkonsumsi Buah Lokal diwilayah Jakarta Barat sebesar 0,266 kali dengan menganggap variabel yang lain konstan. Pada pengujian persepsi (X2) terhadap Perilaku Konsumen dalam Mengkonsumsi Buah Lokal pada tingkat kepercayaan $95 \%$ menunjukan bahwa nilai thitung sebesar 3,444 lebih besar dari nilai 
tTabel $(3,444>1,985)$ dan memiliki nilai signifikansi lebih kecil dari nilai $\alpha$ $(0,001<0,005)$ sehingga berdasarkan hal tersebut, variabel independen persepsi berpengaruh nyata (signifikan) terhadap variabel dependen Perilaku Konsumen dalam Mengkonsumsi Buah Lokal di kawasan Jakarta Barat.

Berdasarkan karakteristik responden dapat diketahui bahwa konsumen di Kawasan Perpasaran Jakarta Barat mayoritas adalah wanita, usia antara 35-42 tahun dengan status sudah menikah, jenis pekerjaan karyawan dengan berpenghasilan Rp. 2.400.001,00 Rp. 5.000.000,00 yang memiliki tanggapan mengenai harapan, kesegaran buah lokal, warna buah lokal, aroma buah lokal, kematangan buah lokal, rasa buah lokal, dan ketersediaan buah lokal berada pada kategori tinggi di Kawasan Perpasaran Jakarta Barat. Dengan demikian, persepsi responden mengenai Perilaku Konsumen dalam Mengkonsumsi Buah Lokal di Kawasan Perpasaran Jakarta Barat sudah baik.

\section{Pengaruh Preferensi Konsumen Terhadap Perilaku Konsumen dalam Mengkonsumsi Buah Lokal di Kawasan Perpasaran Jakarta Barat Hasil dugaan pengaruh} preferensi (X3) terhadap Perilaku Konsumen dalam Mengkonsumsi Buah Lokal (Y) adalah sebesar 0,432 dan nilai koefisien bertanda positif, artinya jika tingkat preferensi naik satu satuan, maka akan menyebabkan bertambahnya peluang Perilaku Konsumen dalam Mengkonsumsi Buah Lokal diwilayah Jakarta Barat sebesar 0,432 kali dengan menganggap variabel yang lain konstan. Pada pengujian preferensi (X3) terhadap Perilaku Konsumen dalam Mengkonsumsi Buah Lokal pada tingkat kepercayaan $95 \%$ menunjukan bahwa nilai thitung sebesar 3,005 lebih besar dari nilai tTabel $(3,005>$ 1,985) dan memiliki nilai signifikansi lebih kecil dari nilai $\alpha(0,004<0,005)$, sehingga berdasarkan hal tersebut variabel independen preferensi berpengaruh nyata (signifikan) terhadap variabel dependen Perilaku Konsumen dalam Mengkonsumsi Buah Lokal di Kawasan Perpasaran Jakarta Barat.

Berdasarkan karakteristik responden dapat diketahui bahwa konsumen di Kawasan Perpasaran Jakarta Barat mayoritas adalah wanita, usia antara 35-42 tahun dengan status sudah menikah, jenis pekerjaan dengan berpenghasilan Rp.2.400.001,00 - Rp.5.000.000,00 yang memiliki tanggapan mengenai tindakan membeli buah lokal, kepuasan mengkonsumsi buah lokal, dan kepentingan membeli buah lokal berada pada kategori tinggi di Kawasan Perpasaran Jakarta Barat. Dengan demikian, preferensi konsumen mengenai Perilaku Konsumen dalam Mengkonsumsi Buah Lokal di Kawasan Perpasaran Jakarta Barat sudah baik.

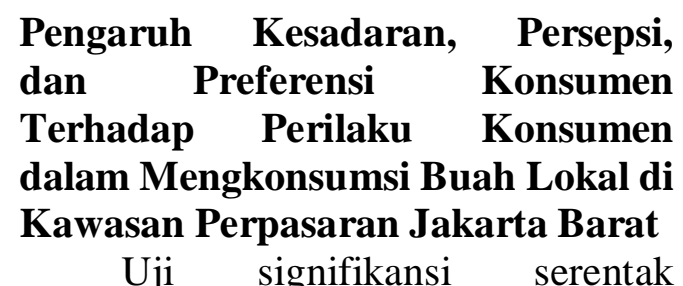
parameter dugaan (uji F) digunakan untuk menunjukan semua variabel independen yang dimasukkan kedalam model mempunyai pengaruh secara 
bersama-sama terhadap variabel dependen. Uji ini membendingkan antara nilai Fhitung dengan nilai FTabel atau dari perbandingan probabilitasnya.

Berdasarkan jumlah sampel yang diteliti yaitu sebanyak 100 responden dan jumlah varibel sebanyak 4 variabel. Maka untuk mencari FTabel menggunakan rumus df $1=\mathrm{k}-$ 1 sedangkan df $2=\mathrm{n}-\mathrm{k}$, maka df $1=\mathrm{k}$ $1=4$ (jumlah variabel) $-1=3$ sedangkan $\mathrm{df} 2=\mathrm{n}-\mathrm{k}=100-4=$ 96. Pengujian dilakukan pada $\alpha=5 \%$, maka nilai fTabel adalah 2,70.

Nilai Fhitung sebesar 36,756 lebih besar dari FTabel 2,70 dan nilai siginfikansi lebih kecil dari nilai $\alpha$ $(0,000<0,05)$. Berdasarkan hasil olahan data tersebut, maka dapat disimpulkan bahwa secara simultan variabel independen (kesadaran, persepsi, dan preferensi konsumen) memiliki pengaruh yang sangat signifikan terhadap variabel dependen yaitu Perilaku Konsumen dalam Mengkonsumsi Buah Lokal di Kawasan Perpasaran Jakarta Barat.

Dari uraian variabel kesadaran, persepsi, dan preferensi terdapat keselarasan yang sama dimana ketiga variabel tersebut berada pada kategori tinggi. Dari variabel-variabel dependen pada penelitian ini, pengaruh yang dominan atas variabel independen (Perilaku Konsumen dalam Mengkonsumsi Buah Lokal) adalah Kesadaran, yang berarti variabel ini adalah yang paling berpengaruh dalam pembentukan Perilaku Konsumen dalam Mengkonsumsi Buah Lokal. Kesadaran adalah penerimaan sebuah produk dalam benak konsumen. Jadi semakin tinggi tingkat pengetahuan tentang buah lokal berarti buah lokal tersebut berada dalam benak konsumen sebelum buah impor yang selanjutnya membentuk persepsi dan preferensi konsumen sebelum akhirnya terbentuk Perilaku Konsumen dalam Mengkonsumsi Buah Lokal di Kawasan Perpasaran Jakarta Barat.

Jika hasil variabel persepsi dan preferensi dikaitkan dengan penelitian terdahulu yang dilakukan oleh Azizah (2008) terdapat persamaan hasil, yang membuktikan bahwa terdapat pengaruh persepsi dan preferensi konsumen terhadap keputusan pembelian buah lokal di Lailai Market Buah Malang. Namun ada sedikit perbedaan dari penelitian dahulu tersebut, yaitu variabel independen pada penelitian terdahulu tentang keputusan pembelian buah lokal tetapi pada penelitian ini variabel independen berupa Perilaku Konsumen dalam Mengkonsumsi Buah Lokal. Sehingga dapat disimpulkan bahwa, keputusan pembelian buah lokal yang dilakukan oleh konsumen belum pasti terdapat Perilaku Konsumen dalam Mengkonsumsi Buah Lokal yang dibeli oleh konsumen tersebut.

Berdasarkan hasil penelitian yang dilakukan oleh Martias (1997), untuk dapat mengembangkan jenis buah-buahan yang sesuai dengan karakteristik perilaku konsumsi konsumen buah-buahan, kegiatan pemasaran modern harus mengutamakan penyesuaian strategi pemasaran dengan karakteristik, keinginan, dan kebutuhan konsumen. Hal ini penting sebagai informasi dalam usaha meningkatkan mutu buah, menentukan jenis buah-buahan yang sesuai dengan selera konsumen, serta untuk dijadikan pedoman dalam pendistribusian buah- buahan 
ketempat-tempat penjualan buah tertentu yang dihubungkan dengan pilihan atau perilaku konsumsi konsumen buah-buahan.

\section{KESIMPULAN DAN SARAN Kesimpulan}

Berdasarkan hasil dan pembahasan pada bab sebelumnya, bahwa konsumen di Kawasan Perpasaran Jakarta Barat mayoritas adalah wanita, usia antara 35-42 tahun dengan status sudah menikah, dan jenis pekerjaan karyawan dengan berpenghasilan Rp. 2.400.001,00 - Rp. 5.000.000,00. Variabel Kesadaran Konsumen (X1), Persepsi Konsumen (X2) dan Preferensi Konsumen (X3) terhadap Perilaku Konsumen Dalam Mengkonsumsi Buah Lokal dengan koefisien determinan sebesar 0,535 atau 53,5\% dan memiliki kesimpulan sebagai berikut :

1. Variabel Kesadaran Konsumen (X1) berpengaruh nyata dan berada pada kategori tinggi terhadap Perilaku Konsumen dalam Mengkonsumsi Buah Lokal di Kawasan Perpasaran Jakarta Barat.

2. Variabel Persepsi Konsumen (X2) berpengaruh nyata dan berada pada kategori tinggi terhadap Perilaku Konsumen dalam Mengkonsumsi Buah Lokal di Kawasan Perpasaran Jakarta Barat.

3. Variabel Preferensi konsumen (X3) berpengaruh nyata dan berada pada kategori tinggi terhadap Perilaku Konsumen dalam Mengkonsumsi Buah Lokal di Kawasan Perpasaran Jakarta Barat.
4. Secara bersama-sama atau simultan, Kesadaran (X1), Persepsi (X2), Preferensi (X3) memiliki pengaruh nyata terhadap variabel Perilaku Konsumen dalam Mengkonsumsi Buah di Kawasan Perpasaran Jakarta Barat dengan Perilaku Konsumen dalam Mengkonsumsi Buah berada pada kategori tinggi.

\section{Saran}

Setelah memperlihatkan kesimpulan diatas, penulis mencoba mengemukakan saran-saran yang mungkin bermanfaat, yaitu sebagi berikut :

1. Pemerintah Kota Administrasi Jakarta Barat sebaiknya memaksimalkan perhatian terhadap buah lokal melalui persediaan buah lokal diberbagai jenis pasar, promosi, pembinaan dan pengawasan petani buah lokal dalam produksi sampai ke pemasaran buah, dan workshop tentang buah lokal untuk menambah pengetahuan konsumen mengenai buah lokal karena variabel kesadaran, persepsi, dan preferensi konsumen berpengaruh nyata terhadap perilaku konsumen dalam mengkonsumsi buah lokal di kawasan perpasaran Jakarta Barat.

2. Bagi peneliti selanjutnya, diharapkan dilakukan di berbagai banyak tempat atau kota sehingga dapat di bandingkan hasil penelitiannya. Bagi penelitian selanjutnya, diharapkan dapat menambah jumlah variabel agar menambah 
kemampuan model dalam

menjelaskan fenomena

perilaku mengkonsumsi buah lokal.
* Alamat Korespondensi:

siti.rochaeni@uinjkt.ac.id 
Jurnal Agribisnis, Vol. 12, No. 2, Desember 2018, [86 - 95]

ISSN : 1979-0058 